\title{
HSOA International Journal of Case Reports and Therapeutic Studies
}

\section{Primary Squamous Cell Carci- noma of the Renal Parenchyma: A Rare Case with Review of Literature}

\author{
K.Oualla $^{1 *}$, N. Acharfi' ${ }^{1}$, Z.Benbrahim ${ }^{1}$, S.Arifi' ${ }^{1}$, T.Bouhafa $^{2}$, \\ K. Hassouni ${ }^{2}$ and N. Mellas ${ }^{1}$
}

'Department of Medical Oncology, Hassan II University, Fes, Morocco

${ }^{2}$ Department of Radiotherapy, Hassan II University, Fes, Morocco

\begin{abstract}
Primary renal squamous cell carcinoma (SCC) is an extremely rare primary malignancy of the kidney withonly few cases that have been reported in the literature. The indolent course of the disease and the lack of specific clinical and radiological features may be responsible of the delay in the diagnosis leading to an advanced stage of disease at diagnosis with poor outcomes. We present the case of a 65-year-old man with long standing renal stone disease and recurrent pyelonephritis in his history, admitted for management of locally advanced renal tumor with distant metastases where histology of biopsy revealed SCC. We report this case to underline the rarity of the renal location as primary site of squamous cell carcinoma, the clinic-radiological and histopathologic features, in addition to treatment management and prognosis.
\end{abstract}

Keywords: Calculi; Chemotherapy; Kidney; Prognosis; Sqamous Cell Carcinoma

\section{Introduction}

Kidney is an extremely rare primary site of Squamous Cell Carcinoma (SCC). It accounts less than $1 \%$ of all urinary tract malignancies [1] and it is usually associated with urolithiasis and hydronephrosis. The diagnosis is often delayed because of the absence of specific signs leading to the diagnosis at advanced stages with poor therapeutic results.

*Corresponding author: Karima Oualla, Department of Medical Oncology, Hassan II University, Fes, Morocco, Tel: + 212 676610267, E-mail: karimarauf@hotmail.com

Citation: Oualla K, Acharfi N, Benbrahim Z, Arifi S, Bouhafa T, et al. (2019) Primary Squamous Cell Carcinoma of the Renal Parenchyma: A Rare Case with Review of Literature. Int J Case Rep Ther Stud 1: 007.

Received: December 17, 2019; Accepted: December 27, 2019; Published: December 31, 2019

Copyright: (c) 2019 Oualla K, et al. This is an open-access article distributed under the terms of the Creative Commons Attribution License, which permits unrestricted use, distribution, and reproduction in any medium, provided the original author and source are credited.

\section{Case Presentation}

We report the case of a 65 -year-old man. His medical history is marked by active smoking and long standing renal stone disease with recurrent pyelonephritis. He presented 4 months before his admission in our department of medical oncology at Hassan II University Hospital, pain over left flank region associated with important loss of weight $(12 \mathrm{~kg})$ then complicated by gross hematuria. Physical examination of the abdomen found a painful percussion on the left kidney area. Hematological and biochemical parameters especially renal function tests were normal. Plain radiograph of the abdomen showed a voluminous left renal calculi with hydronephrosis (Figure 1).

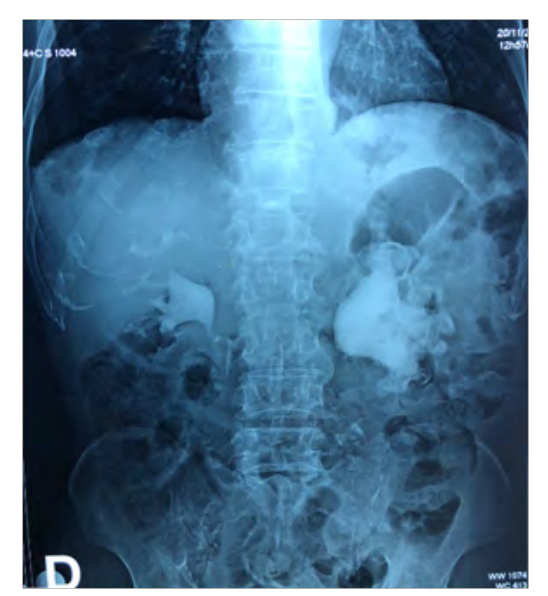

Figure 1: Plain radiograph of the abdomen showing a voluminous left renal calculi with hydronephrosis.

Renal CT scan showed a big left kidney with staghorn calculi and a voluminous renal tumor locally advanced asoociated with a mass of the left lumbar fossa measuring evoking a metastatic lesion, and retro-peritoneal and para-aortic lymph nodes (Figures 2 and 3). The thoraco-abdomino-pelvic scan revealed distant metastases in lung, pleura (Figure 4) and bones. It showed also a thrombosis of the left renal vein. Therefore, the renal malignancy was diagnosed as Stage IV. Biopsy report revealed a Squamous Cell Carcinoma (SCC) well differentiated, infiltrating extensively into the surrounding renal parenchyma. Immunohistochemical analysis showed a positive staining for cytokeratin 7 (CK7) and p63. Curative dose of heparin was prescribed for the thrombosis of renal vein and patient has received the first cycle of chemotherapy based on carboplatine (AUC5) and gemcitabine $\left(1000 \mathrm{mg} / \mathrm{m}^{2}\right)$ and the evolution was marked by a rapid deterioration of his performans status.

\section{Discussion}

Primary renal squamous cell carcinoma is a rare kidney tumor accounting for $0.5-0.8 \%$ of all kidney malignancies [1]. It affects mainly the age group of 50-70 years with a slight female predominance. It is characterized by aggressive local behaviour and rapid distant spread. 


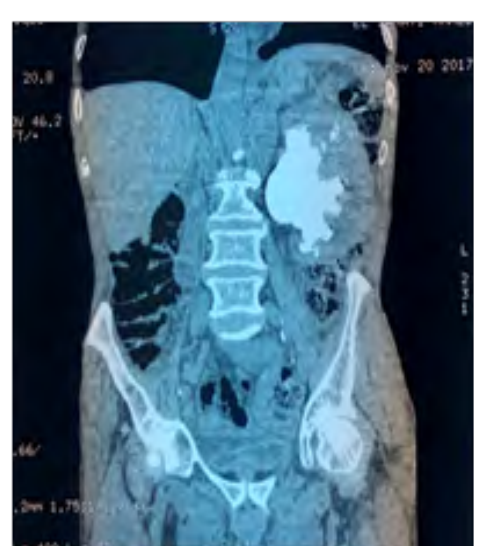

Figure 2: Postcontrast coronal sequence of CT scan showing an irregular mass with renal calculi in the left kidney with hydronephrosis.

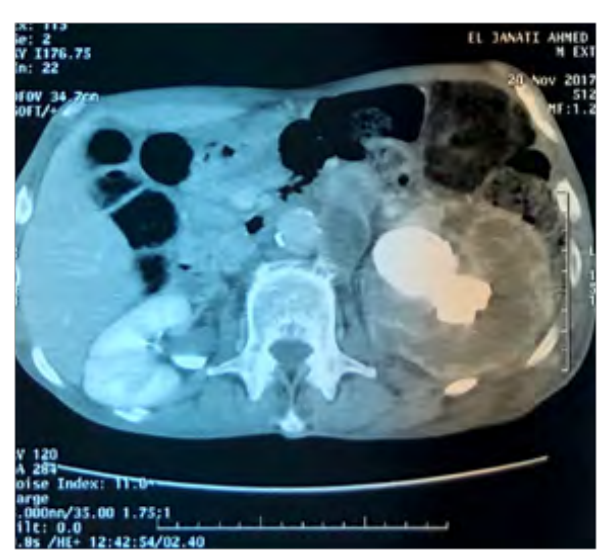

Figure 3: Axial sequence of abdominal CT scan showing an irregular mass in the left kidney with big renal calculi and hydronephrosis.

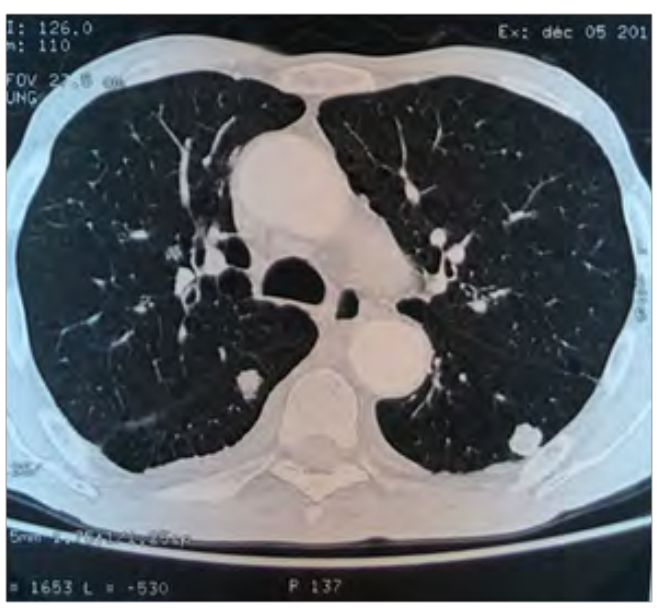

Figure 4: Axial sequence of chest CT scan showing pleural and lung metastases.

Some factors were found to be etiological of renal SCC such as recurrent urinary tract infections, chronic inflammation and renal calculi which are the leading factors $[2,3]$. But the causal association between renal calculi and development of SCC is still unclear [5]. Other factors were also identified including smoking, chemicals, analgesics containing phenacetin, schistosomiasis, vitamin A deficiency, and hormonal imbalance [4,5]. Hydronephrosis was also reported in upper urinary tract carcers and was found to be associated with advanced stages of the disease [6]. Radiologically, there are no specific-imaging features. The CT scan may show a solid mass, with obstruction and hydronephrosis, but it may also reveal a renal infiltrative process without distinct mass $[7,8]$. The main differential diagnosis for a renal SCC associated with calculi is the Xanthogranulomatous Pyelonephritis (XGP), because it is also associated with renal calculi causing an obstruction with hydronephrosis and development of an inflammatory mass destroying the renal parenchyma simulating a primary renal tumor [7,9]. Based on these findings about the strong association between renal SCC with urolithiasis, the long indolent course and the misleading apparence, screening should be considered in patients with known urolithiasis. In our case, the patient presented as apparent risk factors: smooking, long history of renal calculi and recurrent pyelonephritis. Imaging findings showed a large infiltrative tumor in the renal parenchyma of the left kidney, associated with big calculi leading to an important hydronephrosis, and responsible of distant metastases. Given the lack of specific clinical and radiological characterestics in renal SCC histopathological confirmation is required to avoid misleading diagnosis [7]. Histologically, renal SCC is commonly moderately or poorly differentiated and more infiltrative than the transitional cell carcinomas [10]. At Immunohistochemestr, it often stains positive for AE1/AE3, cytokeratin 7 (CK7), and negative for CK20, CEA, S100 and neuroendocrine markers [11]. For patients with early stage of renal SCC, radical surgery is the standard of care [9], while for metastatic stages, there is no standard in treatment and conventional chemotherapy using cisplatin based regimens is still the mainstay of treatment [12] despite the poor results in term of response and the poor survival results with a 5-year survival rate less than $10 \%$ and a median survival of 5 months [13]. Therefore, novel targeted therapeutic approaches are highly needed.

\section{Conclusion}

Primary renal SCC is a rare entity, considered to have a strong association with a renal calculi and urinary tract infections.In the absence of imaging-specific features the diagnosis of SCC should be taken into consideration in patients with risk factors especially long standing renal stone disease.

\section{References}

1. Kalayci OT, Bozdag Z, Sonmezgoz F, Sahin N (2013) Squamous cell carcinoma of the renal pelvis associated with kidney stones: radiologic imaging features with gross and histopathological correlation. J Clin Imaging Sci 3: 14.

2. Kulshreshtha P, Kannan N, Bhardwaj R, Batra S (2012) Primary squamous cell carcinoma of the renal parenchyma. Indian J Pathol Microbiol 55: 370-371.

3. Li MK, Cheung WL (1987) Squamous cell carcinoma of the renal pelvis. J Urol 138: 269-271.

4. Ghosh P, Saha K (2014) Primary intraparenchymal squamous cell carcinoma of the kidney: A rare and unique entity. Case Rep Pathol 2014: 256813.

5. Holmäng S, Lele SM, Johansson SL (2007) Squamous cell carcinoma of the renal pelvis and ureter: incidence, symptoms, treatment and outcome. J Urol 178: 51-56. 
6. Ng CK, Shariat SF, Lucas SM, Bagrodia A, Lotan Y, et al. (2008) Does the presence of hydronephrosis on preoperative axial CT imaging predict worse outcomes for patients undergoing nephroureterectomy for upper-tract urothelial carcinoma? Urol Oncol 29: 27-32.

7. Lee TY, Ko JF, Wan YL, Cheng YF, Yang BY, et al. (1998) Renal squamous cell carcinoma: CT findings and clinical significance. Abdom Imaging 23: 203-208

8. Imbriaco M, Iodice D, Erra P, Terlizzi A, Di Carlo R, et al. (2011) Squamous cell carcinoma within a horseshoe kidney with associated renal stones detected by computed tomography and magnetic resonance imaging. Urology 78: 54-55.

9. Mardi K, Kaushal V, Sharma V (2010) Rare coexistence of keratinizing squamous cell carcinoma with xanthogranulomatous pyelonephritis in the same kidney: Report of two cases. J Cancer Res Ther 6: 339-341.
10. Reuter VE (2004) The urothelial tract: Renal pelvis, ureter, urinarybladder and urethra. In: Mills SE, Carter D, Greeson JK, Oberman HA, Reuter V, Stoler MH, editors. Sterberg's Diagnostic SurgicalPathology. Vol. 4. Philadelphia: Lippincott, Williams and Wilkins; 2004. p. 2058-9.

11. Akatsuka J, Suzuki Y, Nomura S, Yanagi M, Hamasaki T, et al. (2013) A case report of squamous cell carcinoma of the renal pelvis producing granulocyte colony-stimulating factor. Int Cancer Conf J 2013.

12. Raghavendran M, Rastogi A, Dubey D, Chaudhary H, Kumar A, et al. (2003) Stones associated renal pelvic malignancies. Indian J Cancer 40:108-112.

13. Palmer CJ, Atty C, Sekosan M, Hollowell CM, Wille MA (2014) Squamous cell carcinoma of the renal pelvis. Urology 84: 8-11. 


\section{II}

Journal of Anesthesia \& Clinical Care

Journal of Addiction \& Addictive Disorders

Advances in Microbiology Research

Advances in Industrial Biotechnology

Journal of Agronomy \& Agricultural Science

Journal of AIDS Clinical Research \& STDs

Journal of Alcoholism, Drug Abuse \& Substance Dependence

Journal of Allergy Disorders \& Therapy

Journal of Alternative, Complementary \& Integrative Medicine

Journal of Alzheimer's \& Neurodegenerative Diseases

Journal of Angiology \& Vascular Surgery

Journal of Animal Research \& Veterinary Science

Archives of Zoological Studies

Archives of Urology

Journal of Atmospheric \& Earth-Sciences

Journal of Aquaculture \& Fisheries

Journal of Biotech Research \& Biochemistry

Journal of Brain \& Neuroscience Research

Journal of Cancer Biology \& Treatment

Journal of Cardiology: Study \& Research

Journal of Cell Biology \& Cell Metabolism

Journal of Clinical Dermatology \& Therapy

Journal of Clinical Immunology \& Immunotherapy

Journal of Clinical Studies \& Medical Case Reports

Journal of Community Medicine \& Public Health Care

Current Trends: Medical \& Biological Engineering

Journal of Cytology \& Tissue Biology

Journal of Dentistry: Oral Health \& Cosmesis

Journal of Diabetes \& Metabolic Disorders

Journal of Dairy Research \& Technology

Journal of Emergency Medicine Trauma \& Surgical Care

Journal of Environmental Science: Current Research

Journal of Food Science \& Nutrition

Journal of Forensic, Legal \& Investigative Sciences

Journal of Gastroenterology \& Hepatology Research

Journal of Gerontology \& Geriatric Medicine
Journal of Genetics \& Genomic Sciences

Journal of Hematology, Blood Transfusion \& Disorders

Journal of Human Endocrinology

Journal of Hospice \& Palliative Medical Care

Journal of Internal Medicine \& Primary Healthcare

Journal of Infectious \& Non Infectious Diseases

Journal of Light \& Laser: Current Trends

Journal of Modern Chemical Sciences

Journal of Medicine: Study \& Research

Journal of Nanotechnology: Nanomedicine \& Nanobiotechnology

Journal of Neonatology \& Clinical Pediatrics

Journal of Nephrology \& Renal Therapy

Journal of Non Invasive Vascular Investigation

Journal of Nuclear Medicine, Radiology \& Radiation Therapy

Journal of Obesity \& Weight Loss

Journal of Orthopedic Research \& Physiotherapy

Journal of Otolaryngology, Head \& Neck Surgery

Journal of Protein Research \& Bioinformatics

Journal of Pathology Clinical \& Medical Research

Journal of Pharmacology, Pharmaceutics \& Pharmacovigilance

Journal of Physical Medicine, Rehabilitation \& Disabilities

Journal of Plant Science: Current Research

Journal of Psychiatry, Depression \& Anxiety

Journal of Pulmonary Medicine \& Respiratory Research

Journal of Practical \& Professional Nursing

Journal of Reproductive Medicine, Gynaecology \& Obstetrics

Journal of Stem Cells Research, Development \& Therapy

Journal of Surgery: Current Trends \& Innovations

Journal of Toxicology: Current Research

Journal of Translational Science and Research

Trends in Anatomy \& Physiology

Journal of Vaccines Research \& Vaccination

Journal of Virology \& Antivirals

Archives of Surgery and Surgical Education

Sports Medicine and Injury Care Journal

International Journal of Case Reports and Therapeutic Studies

Submit Your Manuscript: http://www.heraldopenaccess.us/Online-Submission.php 